\title{
Cerebral Venous Sinus Thrombosis in a Pediatric Patient With COVID-19
}

Hyaissa Ippolito Bastidas, MD, Trinidad Márquez-Pérez, MD, Alberto García-Salido, PhD, Davide Luglietto, MD, Rafael García Moreno, MD, Amelia Martínez de Azagra-Garde, PhD, Montserrat Nieto-Moro, PhD, Inés Leoz-Gordillo, PhD, Marcelo Budke, PhD, and Belén Rivero-Martín, MD

\author{
Correspondence \\ Dr. Ippolito Bastidas \\ hyaissa.ippolito@gmail.com
}

Neurology: Clinical Practice April 2021 vol. 11 no. 2 e208-e210 doi:10.1212/CPJ.0000000000000899

We present a pediatric patient with coronavirus disease 2019 (COVID-19) associated with multiple cerebral venous sinus thrombosis and venous infarction. Some cases of deep vein thrombosis and pulmonary thromboembolism in COVID-19 have been described ${ }^{1}$ as well as ischemic stroke in adults. ${ }^{2}$ However, this is a rare case of cerebral venous sinus thrombosis in a patient diagnosed with the novel coronavirus.

\section{Case}

A 13-year-old female child, with a persistent oval foramen successfully treated at the first year of life and no other known comorbidities, presented to the emergency department with impaired consciousness and intense headache (visual analog scale of 8). Her parents reported symptoms beginning a week before: fever, cough, and odynophagia, followed by frontal headache and vomiting.

On physical examination, the patient was hemodynamically stable, with a Glasgow Come Scale score of 14, bradypsychia, and no focal neurologic deficit or meningeal signs. Urgent head CT scan revealed right occipital intracerebral hemorrhage, and magnetic resonance angiogram showed bilateral transverse sinus thrombosis with extension to the right sigmoid sinus and internal jugular vein (figure, A and B). A thorax x-ray showed right basal opacity. Initial laboratory tests reported inflammatory markers as mild leukocytosis $\left(14,460\right.$ per $\left.\mathrm{mm}^{3}\right)$ with lymphopenia $\left(1,800\right.$ per $\left.\mathrm{mm}^{3}\right)$, increase of lactate dehydrogenase $322 \mathrm{U} / \mathrm{L}(100-250)$, serum ferritin $240 \mathrm{ng} / \mathrm{mL}$ (7-140), C-reactive protein of $12.55 \mathrm{mg} / \mathrm{dL}$, and abnormal coagulation parameters compatible with overt-disseminated intravascular coagulation ${ }^{3}$ such as platelet count of 55,000 per $\mathrm{mm}^{3}$, prothrombin index of $43 \%$ (75-110), fibrinogen of $0 \mathrm{mg} / \mathrm{dL}$, and D-dimer of $33.96 \mathrm{mg} / \mathrm{L}(0-0.5)$.

The patient was admitted to the pediatric intensive care unit. Intravenous hydration, empiric antibiotics, and intracranial hypertension medical treatment were started, requiring hypertonic saline bolus for bradycardia episodes $(35 \mathrm{bpm})$. Fibrinogen and platelet and plasma transfusion were administered. PCR for severe acute respiratory syndrome coronavirus 2 (SARS-CoV-2) by oropharyngeal swab was positive confirming COVID-19, thus lopinavir-ritonavir, hydroxychloroquine, and azithromycin were also initiated.

Unfractionated heparin anticoagulation was started at an initial infusion rate of $10 \mathrm{U} / \mathrm{kg} / \mathrm{h}$, adjusted to maintain partial thromboplastin time ratio of 1.5-2.5, prompted by bilateral sinus thrombosis, intracranial hypertension symptoms and sings, and the high mortality rate associated, ${ }^{4}$ despite the risk of worsening cerebral hemorrhage.

Department of Neurosurgery (HIB, TM-P, MB, BR-M), Hospital Infantil Universitario Niño Jesús; Department of Intensive Care (AG-S, AMA-G, MN-M, IL-G), Hospital Infantil Universitario Niño Jesús, Madrid; Department of Neurosurgery (DL), Azienda Ospedaliero Universitaria Senese Le Scotte, Siena, Italy; and Department of Neurosurgery (RGM), Complejo Hospitalario Universitario de Badajoz, Badajoz, Spain.

Funding information and disclosures are provided at the end of the article. Full disclosure form information provided by the authors is available with the full text of this article at Neurology.org/cp. 


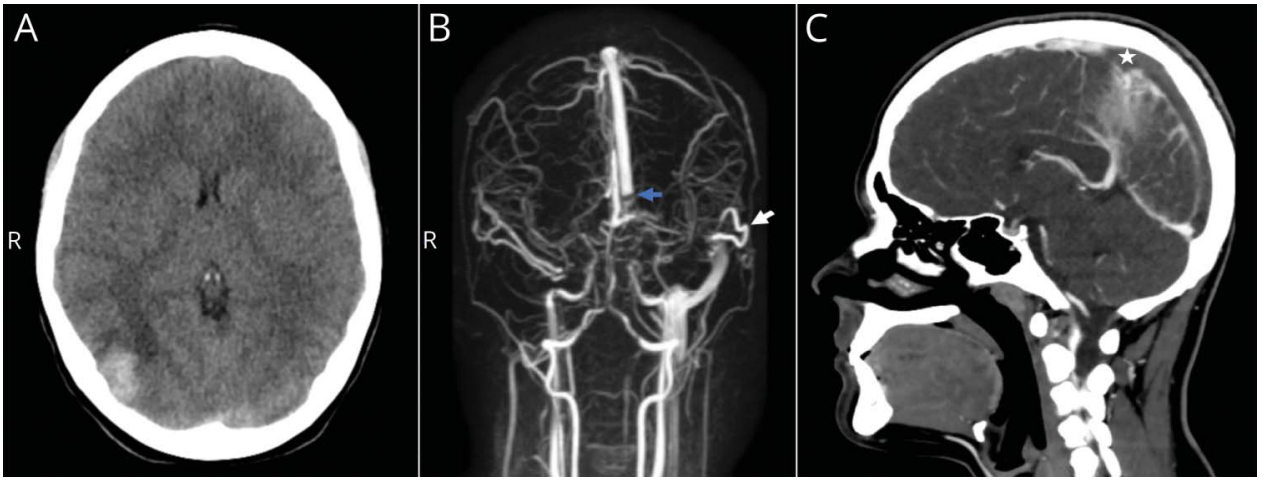

(A) Right occipital intracerebral hemorrhage is seen on initial head $C T$ scan. (B) Anteroposterior view of initial 3D MRA shows venous flow occlusion at the final part of superior sagittal sinus (blue arrow) due to bilateral transverse sinus thrombosis extending to the right jugular vein. Left sigmoid sinus is filled by the vein of Labbé (white arrow). (C) Head contrast CT scan on follow-up demonstrates repletion defect in the posterior half of superior sagittal sinus (white star). MRA = MR angiogram.

Over the subsequent 72 hours, there was progressive clinical improvement. However, on the fifth day of admission, body angio-CT scan revealed thrombosis progression toward the posterior half of the superior sagittal sinus (figure, C), as well as bilateral pulmonary thromboembolism and bilateral deep femoral and iliac veins thrombosis reaching infrarenal cava, associating left leg edema as the sole clinical sign and no hemodynamic changes. Thus, anticoagulation doses were increased at $20 \mathrm{U} / \mathrm{kg} / \mathrm{h}$.

Regarding multiple vein thrombosis, the patient did not have a family history of autoimmune disease or genetic prothrombotic condition. Mycoplasma, parvovirus, Toxoplasma gondii, cytomegalovirus, Epstein-Barr, Varicella zoster, Herpes simplex 1 and 2, hepatitis B and C viruses, and HIV were ruled out. The autoimmune panel for lupus and antiphospholipid syndrome only showed a weak positive for lupus anticoagulant. However, at a 2-week follow-up a slight increase of aCL IgG $23 \mathrm{U} / \mathrm{mL}(0-20)$ was also noted. Both parameters were normalized 1 month later. In addition, protein $C$ and $S$, homocysteine, antithrombin III, and anti Xa were also normal. Mutation for factor V Leiden and prothrombin 20210 were negative.

Despite the severe coagulopathy developed by our patient with COVID-19, the known associated poor prognosis, ${ }^{4}$ and the severity of the cerebral venous sinus thrombosis, the child was discharged with good clinical outcome, asymptomatic and without neurologic sequelae after 24 days of admission.

\section{Discussion}

SARS-CoV-2 infection has been associated with a hypercoagulable state and potential thrombogenic risk. ${ }^{2}$ It is believed to be due to the inflammatory response induced by the viral infection with endothelium dysfunction and tissue factor expression, which promotes a coagulation activation and possible thrombi formation and hyperfibrinolysis. ${ }^{2,5}$
Antiphospholipid antibodies can be transiently present at low levels in the context of viral infections, ${ }^{6}$ in accordance to the tests results in our patient and other COVID-19 cases with strokes. ${ }^{2,5}$ This could be a contributing postinfection mechanism for further extensive thrombi formation. Conversely, it is also possible that an underlying autoimmune condition triggered by the virus could exist. The latter seems less likely in our case because of normalized antibodies levels on subsequent follow-up.

We believe the postinfectious mechanism in addition to the endothelial injury and systemic inflammatory response may have promoted a prothrombotic state in our patient with vascular venous occlusion leading to a massive coagulation activation until consumption. Nevertheless, the pathophysiology of thrombotic complications in COVID-19 is still uncertain and further studies are needed to be conclusive. Although unlikely, the possibility of coincidental conditions cannot be excluded.

Although an indolent development of COVID-19 has been described in most children, ${ }^{7}$ it can exceptionally affect the pediatric population with a severe form, not always associated with chronic comorbidities. This case may set a precedent to be considered in the current pandemic by the novel coronavirus and its wide range of clinical presentations.

\section{Study Funding}

No targeted funding reported.

\section{Disclosure}

H. Ippolito-Bastidas, T. Márquez-Pérez, A. García-Salido, D. Luglietto, R. García-Moreno, A. Martínez, M. Nieto-Moro, I. Leoz-Gordillo, M. Budke, and B. Rivero-Martín report no disclosures relevant to the manuscript. Full disclosure form information provided by the authors is available with the full text of this article at Neurology.org/cp.

\section{Publication History}

Received by Neurology: Clinical Practice April 24, 2020. Accepted in final form July 2, 2020. 
Appendix Authors

\begin{tabular}{|c|c|c|}
\hline Name & Location & Contribution \\
\hline $\begin{array}{l}\text { Hyaissa } \\
\text { Ippolito } \\
\text { Bastidas, MD }\end{array}$ & $\begin{array}{l}\text { Hospital Infantil } \\
\text { Universitario Niño } \\
\text { Jesús, Madrid, Spain }\end{array}$ & $\begin{array}{l}\text { Designed and } \\
\text { conceptualized the study, } \\
\text { has a major role in } \\
\text { interpretation of data, and } \\
\text { drafted the manuscript for } \\
\text { intellectual content }\end{array}$ \\
\hline $\begin{array}{l}\text { Trinidad } \\
\text { Márquez- } \\
\text { Pérez, MD }\end{array}$ & $\begin{array}{l}\text { Hospital Infantil } \\
\text { Universitario Niño } \\
\text { Jesús, Madrid, Spain }\end{array}$ & $\begin{array}{l}\text { Conceptualized the study } \\
\text { and drafted and revised the } \\
\text { manuscript }\end{array}$ \\
\hline $\begin{array}{l}\text { Alberto } \\
\text { García-Salido, } \\
\text { PhD }\end{array}$ & $\begin{array}{l}\text { Hospital Infantil } \\
\text { Universitario Niño } \\
\text { Jesús, Madrid, Spain }\end{array}$ & $\begin{array}{l}\text { Conceptualized the study, } \\
\text { participated in } \\
\text { interpretation of the data, } \\
\text { and revised the manuscript }\end{array}$ \\
\hline $\begin{array}{l}\text { Davide } \\
\text { Luglietto, MD }\end{array}$ & $\begin{array}{l}\text { Azienda Ospedaliero } \\
\text { Universitaria Senese Le } \\
\text { Scotte, Siena, Italy }\end{array}$ & Revised the manuscript \\
\hline $\begin{array}{l}\text { Rafael García } \\
\text { Moreno, MD }\end{array}$ & $\begin{array}{l}\text { Complejo Hospitalario } \\
\text { Universitario de } \\
\text { Badajoz, Badajoz, Spain }\end{array}$ & $\begin{array}{l}\text { Drafted and revised the } \\
\text { manuscript for intellectual } \\
\text { content }\end{array}$ \\
\hline $\begin{array}{l}\text { Amelia } \\
\text { Martínez de } \\
\text { Azagra-Garde, } \\
\text { MD }\end{array}$ & $\begin{array}{l}\text { Hospital Infantil } \\
\text { Universitario Niño } \\
\text { Jesús, Madrid, Spain }\end{array}$ & Acquisition of data \\
\hline $\begin{array}{l}\text { Montserrat } \\
\text { Nieto-Moro, } \\
\text { MD }\end{array}$ & $\begin{array}{l}\text { Hospital Infantil } \\
\text { Universitario Niño } \\
\text { Jesús, Madrid, Spain }\end{array}$ & Acquisition of data \\
\hline
\end{tabular}

Appendix (continued)

\begin{tabular}{lll}
\hline Name & Location & Contribution \\
\hline $\begin{array}{l}\text { Inés Leoz- } \\
\text { Gordillo, MD }\end{array}$ & $\begin{array}{l}\text { Hospital Infantil } \\
\text { Universitario Niño } \\
\text { Jesús, Madrid, Spain }\end{array}$ & Acquisition of data \\
\hline $\begin{array}{l}\text { Marcelo } \\
\text { Budke, PhD }\end{array}$ & $\begin{array}{l}\text { Hospital Infantil } \\
\text { Universitario Niño } \\
\text { Jesús, Madrid, Spain }\end{array}$ & Revised the manuscript \\
\hline $\begin{array}{l}\text { Belén Rivero- } \\
\text { Martín, MD }\end{array}$ & $\begin{array}{l}\text { Hospital Infantil } \\
\text { Universitario Niño } \\
\text { Jesús, Madrid, Spain }\end{array}$ & $\begin{array}{l}\text { Revised and approved the } \\
\text { final version of the } \\
\text { manuscript }\end{array}$ \\
\hline
\end{tabular}

\section{References}

1. Klok FA, Kruip MJHA, van der Meer NJM, et al. Incidence of thrombotic complications in critically ill ICU patients with COVID-19. Thromb Res 2020;191:145-147.

2. Zhang Y, Xiao M, Zhang S, et al. Coagulopathy and antiphospholipid antibodies in patients with covid-19. N Engl J Med 2020;382:e38.

3. Taylor J, Toh CH, Hoots WK, Wada H, Levi M. Towards definition, clinical and laboratory criteria, and a scoring system for disseminated intravascular coagulation. Thromb Haemost 2001;86:1327-1330.

4. Tang N, Li D, Wang X, Sun Z. Abnormal coagulation parameters are associated with poor prognosis in patients with novel coronavirus pneumonia. J Thromb Haemost 2020;18:844-847.

5. Beyrouti R, Adams ME, Benjamin L, et al. Characteristics of ischaemic stroke associated with COVID-19. J Neurol Neurosurg Psychiatry 2020;jnnp-2020-323586

6. Plummer MP, Young AMH, O'Leary R, Damian MS, Lavinio A. Probable catastrophic antiphospholipid syndrome with intracerebral hemorrhage secondary to Epstein-Barr viral infection. Neurocrit Care 2018;28:127-132.

7. Ludvigsson JF. Systematic review of COVID-19 in children shows milder cases and a better prognosis than adults. Acta Paediatr 2020;109:1088-1095. 


\section{Neurology ${ }^{\circ}$ Clinical Practice}

Cerebral Venous Sinus Thrombosis in a Pediatric Patient With COVID-19 Hyaissa Ippolito Bastidas, Trinidad Márquez-Pérez, Alberto García-Salido, et al. Neurol Clin Pract 2021;11;e208-e210 Published Online before print July 8, 2020

DOI 10.1212/CPJ.0000000000000899

This information is current as of July 8, 2020

\begin{abstract}
Updated Information \& Services

References

Subspecialty Collections

Permissions \& Licensing

Reprints

including high resolution figures, can be found at: http://cp.neurology.org/content/11/2/e208.full.html

This article cites 6 articles, 0 of which you can access for free at: http://cp.neurology.org/content/11/2/e208.full.html\#\#ref-list-1

This article, along with others on similar topics, appears in the following collection(s):

Cerebral venous thrombosis

http://cp.neurology.org//cgi/collection/cerebral_venous_thrombosis COVID-19

http://cp.neurology.org//cgi/collection/covid_19

Intracerebral hemorrhage

http://cp.neurology.org//cgi/collection/intracerebral_hemorrhage

Viral infections

http://cp.neurology.org//cgi/collection/viral_infections

Information about reproducing this article in parts (figures,tables) or in its entirety can be found online at:

http://cp.neurology.org/misc/about.xhtml\#permissions

Information about ordering reprints can be found online:

http://cp.neurology.org/misc/addir.xhtml\#reprintsus
\end{abstract}

Neurol Clin Pract is an official journal of the American Academy of Neurology. Published continuously since 2011, it is now a bimonthly with 6 issues per year. Copyright (C) 2020 American Academy of Neurology. All rights reserved. Print ISSN: 2163-0402. Online ISSN: 2163-0933.

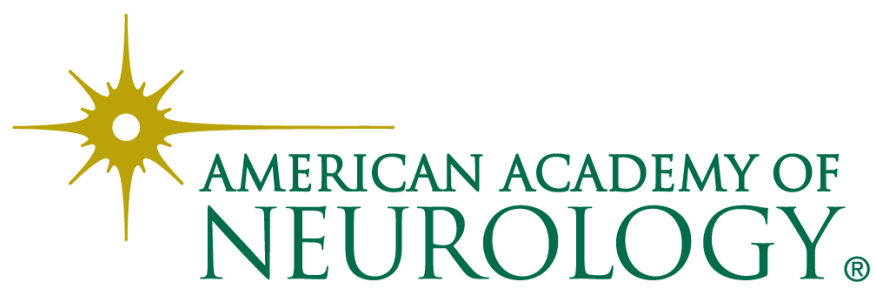

